\title{
"Outsourcing" Diatoms in Fabrication of Metal-Doped 3D Biosilica
}

\author{
Weronika Brzozowska ${ }^{1}$, Myroslav Sprynskyy ${ }^{2, *}{ }^{\mathbb{D}}$, Izabela Wojtczak ${ }^{2}$, Przemysław Dąbek ${ }^{1}$ (i), \\ Andrzej Witkowski ${ }^{1}$ and Bogusław Buszewski ${ }^{2,3}$ \\ 1 Institute of Marine and Environmental Sciences, University of Szczecin, Mickiewicza 16, 70-383 Szczecin, \\ Poland; weronika.brzozowska@phd.usz.edu.pl (W.B.); pdabek@usz.edu.pl (P.D.); \\ Andrzej.Witkowski@usz.edu.pl (A.W.) \\ 2 Department of Environmental Chemistry and Bioanalytics, Faculty of Chemistry, \\ Nicolaus Copernicus University in Toruń, 7 Gagarina Str., 87-100 Toruń, Poland; \\ izabelawojtczak1991@gmail.com (I.W.); bbusz@umk.pl (B.B.) \\ 3 Centre for Modern Interdisciplinary Technologies, Nicolaus Copernicus University, Wilenska 4, \\ 87-100 Torun, Poland \\ * Correspondence: mspryn@chem.umk.pl; Tel.: +48-566-1144-753; Fax: +48-566-114-837
}

Received: 19 May 2020; Accepted: 3 June 2020; Published: 5 June 2020

\begin{abstract}
Diatoms have an ability that is unique among the unicellular photoautotrophic organisms to synthesize an intricately ornamented siliceous (biosilica) exoskeleton with an ordered, hierarchical, three-dimensional structure on a micro- to nanoscale. The unique morphological, structural, mechanical, transport, photonic, and optoelectronic properties of diatomaceous biosilica make it a desirable material for modern technologies. This review presents a summary and discussion of published research on the metabolic insertion of chemical elements with specific functional activity into diatomaceous biosilica. Included in the review is research on innovation in methods of synthesis of a new generation of functional siliceous materials, where the synthesis process is "outsourced" to intelligent microorganisms, referred to here as microtechnologists, by providing them with appropriate conditions and reagents.
\end{abstract}

Keywords: diatoms; diatomaceous biosilica; metal doping; metabolic inserting

\section{Introduction}

The use of microorganisms, especially unicellular microalgae, is a novel approach in the design and synthesis of new inorganic composite nanomaterials [1,2]. Some microorganisms have the ability to synthesize unique mineral composites with complex, hierarchical structures on a micro- to nanoscale [3]. The single-celled photoautotrophic microorganisms—diatoms (Bacillariophyceae)—have an astonishing variety of intricately ornamented siliceous exoskeletons, called frustules or valves, with a unique three-dimensional structure (Figure 1 [4]) in more than 100,000 known species [5]. Such a variety of unique, precise siliceous structures with orderly pore (areola) systems makes them a desirable material for modern technologies [6-14].

The concept of using diatomaceous biosilica as an implementation material in modern technologies, especially in nanotechnology, is relative new and was proposed in 1994 by Gordon R. and Drum R. W. [15]. Since then, the phenomenal ability of diatoms to synthesize unique three-dimensional structures with specific physicochemical (optical, electrical, filtration, thermal, mechanical) properties from amorphous silica has held growing fascination for biologists, chemists, and physicists [6,16-21]. Currently, diatomaceous biosilica, due to its three-dimensional, porous structure, wide availability, and the possibility of biosynthesis through the cultivation of diatoms under artificial conditions, is one 
of the most frequently used substitutes for mesoporous silica materials in modern technologies. These materials, despite their biocompatibility and large specific surface area [22], are difficult to synthesize because of the necessity of considerable financial input, a large amount of energy, and an association of toxic materials using [23].

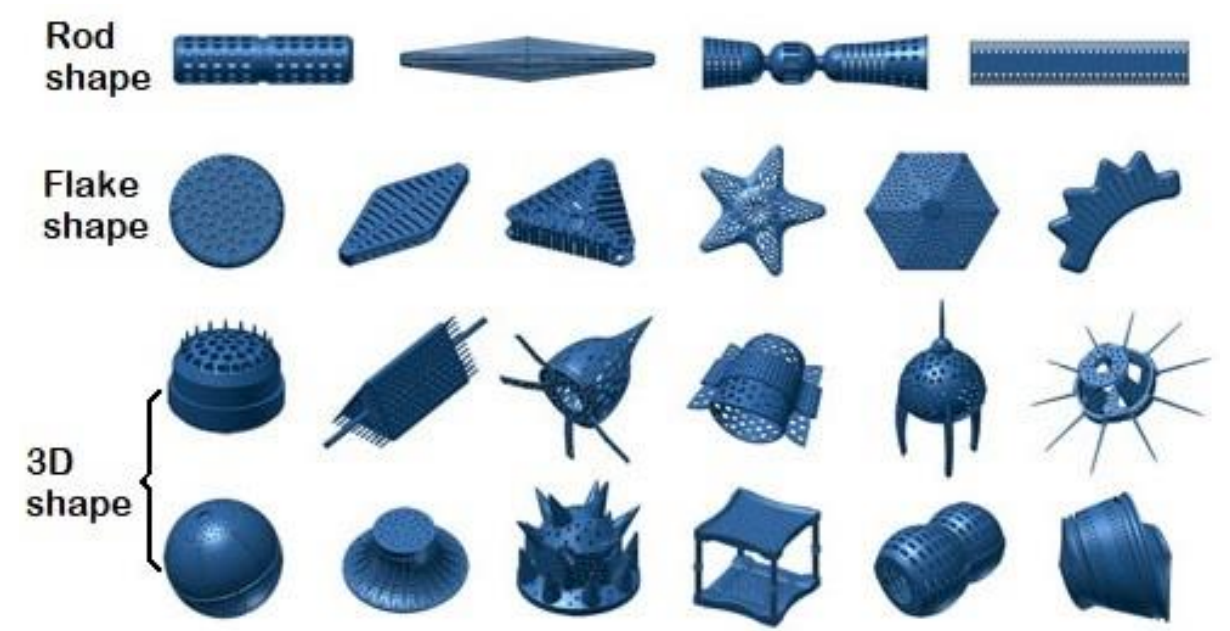

Figure 1. The unique structure of the diatom frustule. The images are 3D models [4].

The unique, hierarchically porous 3D structure of diatom frustules makes them an attractive source of solutions for the development of modern material engineering. There are a wide range of possibilities for the use of such materials, e.g., in the production of biosensors, optical devices, catalysts, semiconductors, effective adsorbents, templates for nanolithography, and in designing drug carriers or bone implants $[6,11,17,18,20,23-25]$. The range of perspectives for the use of diatomaceous biosilica is shown in Figure 2.

Diatomaceous biosilica can be successfully used as an electrode material for energy generation and storage, or as photonic crystals [26-31]. Diatom frustules can be used as microlenses, as they are able to focus light below the diffraction limit, and their ability to accumulate high-intensity light can lead to the development of modern solar cells [32-36]. High thermal and mechanical resistance as well as unique optical properties make diatomaceous biosilica an inspiration in the development of modern optoelectronic devices [23,24,30,37]. However, many of the possible applications for diatomaceous biosilica as an industrial material are limited by the chemistry of the silica in diatom frustules. For this reason, considerable efforts have been made recently to modify the structure of diatom frustules to make them more technologically functional, whilst preserving their unique shape and morphology [23,33,38-42]. An extremely exciting proposal for the modification of biosilica is its reduction to pure silicon, without destroying its three-dimensional structure, which would be associated with new, broad possibilities in the field of microelectronics [18,38]. Promising results have been obtained using diatomaceous biosilica as a matrix in the chemical synthesis of nanomaterials $[20,27,43,44]$. Umernura et al. [41] proposed using fragmented diatomaceous biosilica as a matrix for luminescence in the liquid phase. The potential for placing specific proteins, enzymes, or antibodies within the structure of diatoms could allow for the production of microchip-sized hybrid biosensors, which would be a medical breakthrough [16,18,45].

Test results so far have indicated a great potential for the application of diatomaceous biosilica as a component of solar cells, in place of expensive titanium dioxide [37,46-48]. An extremely interesting but not yet fully developed idea is the ability to modify the structure of diatomaceous biosilica. There are two basic methods for the functionalization of diatoms [49]. The first one is the in vitro method involving the attachment, via a condensation reaction, of functional groups on the surface of the diatomaceous frustule after its purification, i.e., the removal of the organic matrix of the diatomaceous cell. The second one is the in vivo method based on the stable incorporation of the modifying element 
into the nanostructural architecture of diatomaceous biosilica during cultivation [50]. The in vitro method can be used to give magnetic properties to diatom frustules by adding iron nanoparticles treated with dopamine [51], as well as to create antibody matrices that can be applied in such techniques as immunoprecipitation [27]. The functionalization of diatoms in vivo is possible when modifying elements are added to the culture medium. This enables the incorporation of the doping element into the structure of the diatom frustules. So far, a few publications report the ability of diatoms to metabolically introduce metal oxides such as titanium or germanium into the structure of silica frustules $[3,19,52-62]$. There are also results of initial studies on the possibility of metabolic substitution of silicon atoms with nickel, zirconium, tin, zinc, calcium, aluminum, iron, and europium in diatomaceous biosilica $[19,63-71]$.

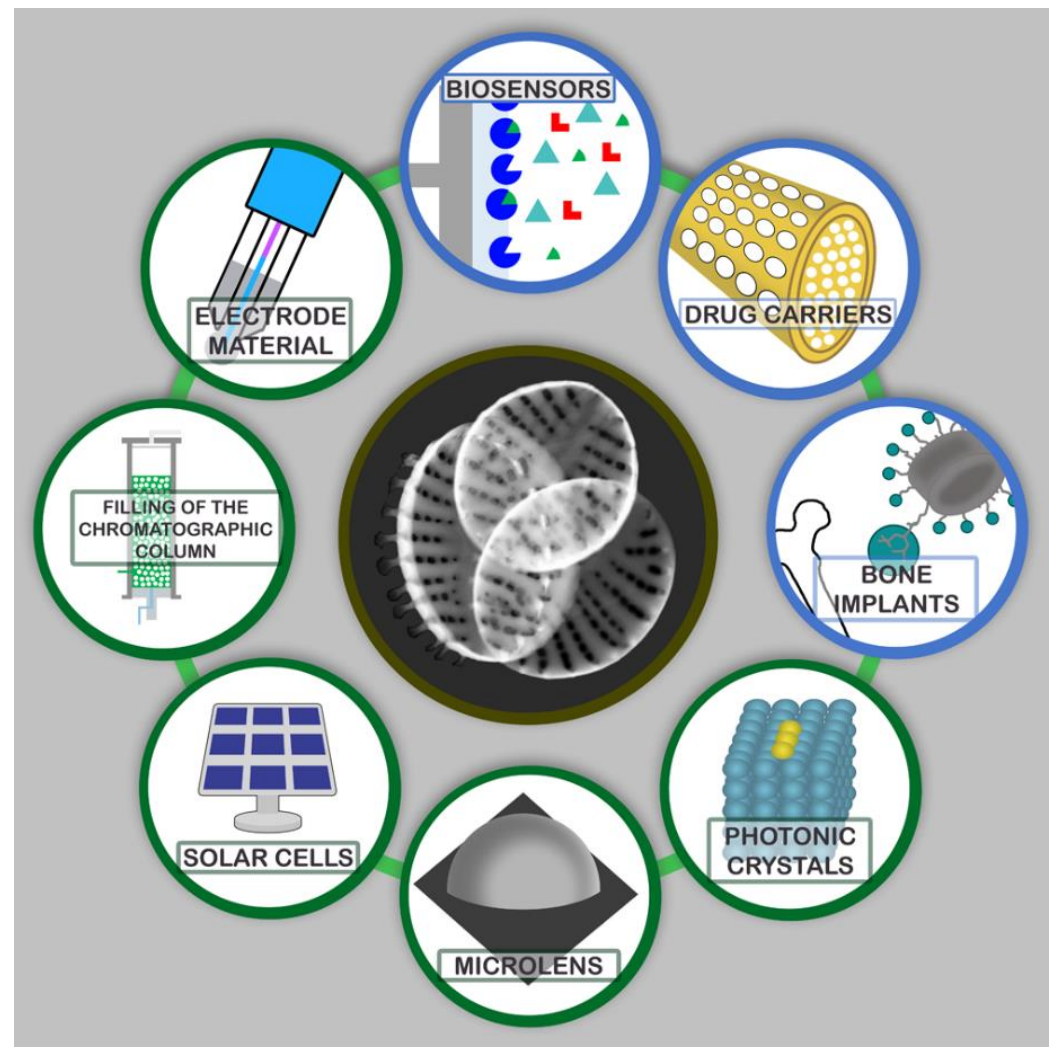

Figure 2. A range of possibilities to use diatomaceous biosilica.

In this review we summarize and discuss the research published to date on the metabolic insertion of chemical elements with specific functional activity (metals or semimetals) into the diatomaceous biosilica structure. Attention is drawn to the culture conditions (culture medium, type of salt and concentration range of admixed elements, $\mathrm{pH}$ ), physicochemical properties of the biosilica obtained, the amount embedded and distribution of the element in the biosilica structure, and prospects for the use of the doped biosilica. We hope this work will encourage interest in metabolic insertion as a novel and innovative approach to the synthesis of new materials, where the synthesis itself is "outsourced" to the microorganisms as "microtechnologists" who need only the appropriate conditions and reagents.

\section{Metabolic Insertion of Diatomaceous Biosilica with Titanium and Germanium Ions}

\subsection{Metabolic Insertion of Diatomaceous Biosilica with Titanium Ions}

There is an outstanding interest in bioinspired approaches for the synthesis of semiconductors and metal oxide, especially titanium dioxide nanomaterials, as they offer the opportunity for self-assembly 
into three-dimensional, hierarchical structures. Cell culture systems have especially been identified as a platform for the biosynthesis of photonic nanostructures [55].

A method for the metabolic insertion of titanium ions into diatom cells, whose scheme is shown in Figure 3 [72], was first developed by C. Jeffryes et al. [55] using an unnamed species representing the genus Pinnularia.

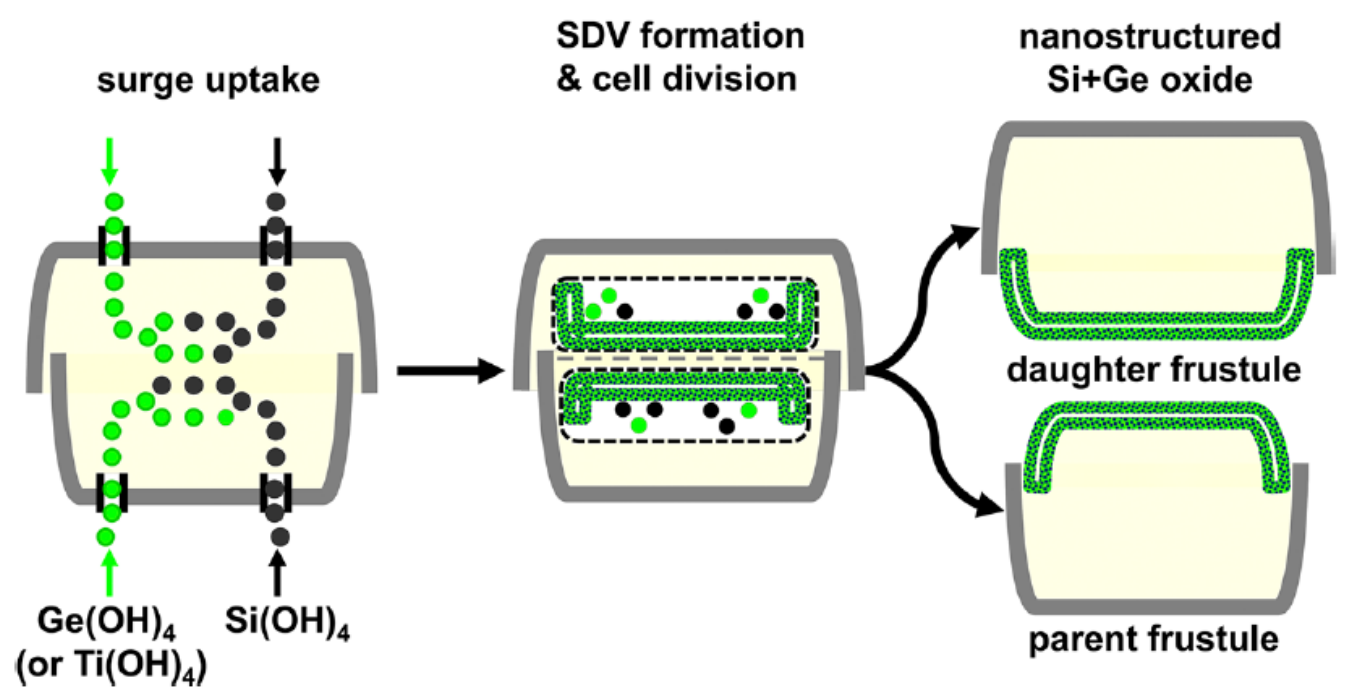

Figure 3. Alleged scheme of metabolic insertion of $\mathrm{Ge}$ or Ti into the diatom frustule during cultivation.

The doping process was carried out in two stages in a specially prepared photobioreactor. In the first stage, diatoms were grown without the presence of a titanium precursor in a culture medium until all silicon was taken up (the initial concentration of silicon was $0.5 \mathrm{mM}$ ). In the second stage, the culture medium was enriched with a solution containing $30 \mathrm{mM}$ of sodium metasilicate and $0.5-4.5 \mathrm{mM}$ of the soluble titanium compound $\mathrm{TiCl}_{4}$, resulting from the dissolution of $\mathrm{TiOSO}_{4}$ and $\mathrm{NaOH}$ in $500 \mathrm{mM}$ $\mathrm{HCl}$. Skolem [58] followed the same pathway, using a two-stage process to dope the siliceous diatom frustule of Pinnularia sp. and Coscinodiscus sp. with titanium ions in a photobioreactor. A series of experiments was conducted: The first phase involved testing the different combinations of levels of silicon starvation, and the second stage consisted of adding a solution containing $3.6-8.9 \mathrm{mM} \mathrm{Si}$ and $0.36-0.62 \mathrm{mM}$ Ti in the form of $\mathrm{TiCl}_{4}$ to the medium. Chauton et al. [57] also used a two-stage process of titanium ion doping on Pinnularia sp., and using the same titanium precursor, they initiated the titanium uptake when the silicon concentration in the culture medium decreased to less than $0.5 \mu \mathrm{m}$. In the study by Eynde et al. [56], the two-stage scheme of the process of doping Pinnularia sp. was analogous, differing only in the timing of the addition of the titanium precursor, which took place at the end of cell growth instead of the time of silicon starvation. A study on the two-stage doping of Fistulifera solaris by Maeda et al. [59] used titanium(IV) bis(ammonium lactate)dihydroxide (TiBALDH) as the precursor.

A one-stage doping process has been used by other research groups. In Basharina's work [19], the culture of Synedra acus was carried out in microincubators in which $10 \mathrm{mM} \mathrm{Na}_{2} \mathrm{SiO}_{3}$ and $10 \mathrm{mM}$ $\mathrm{TiCl}_{4}$ were added simultaneously to a base solution. A similar approach was used by Lang et al. by adding $0.2-2.0 \mathrm{mM}$ TiBALDH to the culture medium of Thalassiosira weissflogii. A comparison of the methods used, the culture parameters, and types of titanium ion precursors is shown in Table 1. 
Table 1. Summary of methods used for the metabolic insertion of titanium ions to diatomaceous biosilica.

\begin{tabular}{|c|c|c|c|c|c|c|c|}
\hline Ref. $^{a}$ & [19] & [55] & [56] & [57] & [58] & [59] & [60] \\
\hline Species & S.ac. ${ }^{\mathrm{b}}$ & P. sp. ${ }^{\mathrm{c}}$ & P. sp. & P. sp. & P. sp.; Cos. sp. ${ }^{\mathrm{d}}$ & F. sol. ${ }^{\mathrm{e}}$ & T. weiss. $\mathrm{f}$ \\
\hline Culture Medium & $\mathrm{DM}$ & $\mathrm{f} / 2$ & WC & $\mathrm{f} / 2$ & $\mathrm{f} / 2$ & $\mathrm{f} / 2$ & $\mathrm{f} / 2$ \\
\hline $\operatorname{Lux}\left[\mu \mathrm{mol} / \mathrm{m}^{2} . \mathrm{s}\right]$ & $13-16$ & 149 & 30 & 130 & 130 & 140 & 246 \\
\hline $\mathrm{T}\left[{ }^{\circ} \mathrm{C}\right]$ & 12 & 22 & 20 & 20 & 20 & 25 & $16-22$ \\
\hline $\mathrm{pH}$ & 7.4 & $8.4-8.6$ & $7.6-8.4$ & $8.0-8.4$ & $8.0-8.35$ & 6.4 & No data \\
\hline Process type & I $\mathrm{g}$ & $\mathrm{II}^{\mathrm{h}}$ & II & II & II & II & I \\
\hline Precursor & $\mathrm{TiCl}_{4}$ & $\mathrm{TiOSO}_{4}{ }^{\mathrm{i}}$ & TiBALDH & $\mathrm{TiOSO}_{4}$ & $\mathrm{TiOSO}_{4}$ & TiBALDH & TiBALDH \\
\hline$[\mathrm{Si}][\mathrm{mM}]^{\mathrm{j}}$ & 10 & 0.48 & No data & 6.2 & $3.6-8.9$ & No data & 0.2 \\
\hline$[\mathrm{Ti}][\mathrm{mM}]^{\mathrm{k}}$ & 10 & $0.0085-0.073$ & $0.0-0.56$ & 0.36 & $0.36-0.62$ & $0.25-20$ & $0.2-2.0$ \\
\hline
\end{tabular}

Notes: ${ }^{a}$ References, ${ }^{\mathrm{b}}$ Synedra acus, ${ }^{\mathrm{c}}$ Pinnularia sp., ${ }^{\mathrm{d}}$ Coscinodiscus sp., ${ }^{\mathrm{e}}$ Fistulifera solaris, ${ }^{\mathrm{f}}$ Thalassiosira weissflogii, $\mathrm{g}$ One-stage process, ${ }^{\mathrm{h}}$ Two-stage process, ${ }^{\mathrm{i}} \mathrm{TiOSO}_{4}+\mathrm{NaOH} / \mathrm{HCl},{ }^{\mathrm{j}} \mathrm{Si}$ content in the culture medium, ${ }^{\mathrm{k}} \mathrm{Ti}$ content in the culture medium.

Works describing the effect of introducing titanium into the structure of diatomaceous biosilica $[57,58,60]$ have indicated a lack of toxic ion effect on diatom cells. There was also no evidence of titanium ions interfering with the cell cycle of doped diatoms, and SEM and TEM studies conducted on doped frustules showed properly developed structures without any aberration in the pore system. Only in Basharina's [19] work can we find information concerning a decrease in mechanical strength of doped biosilica. In most cases, a significant increase in biomass is seen as a result of the metabolic insertion of titanium ions. However, in the experiment conducted by Skolem [58] the yield of diatom biomass was lower when compared with the blank. Research conducted by Eynde et al. [56] on Pinnularia sp. cultures showed that inhibition of the cell growth process depends on the type of titanium precursor used in the breeding medium (Figure 4).

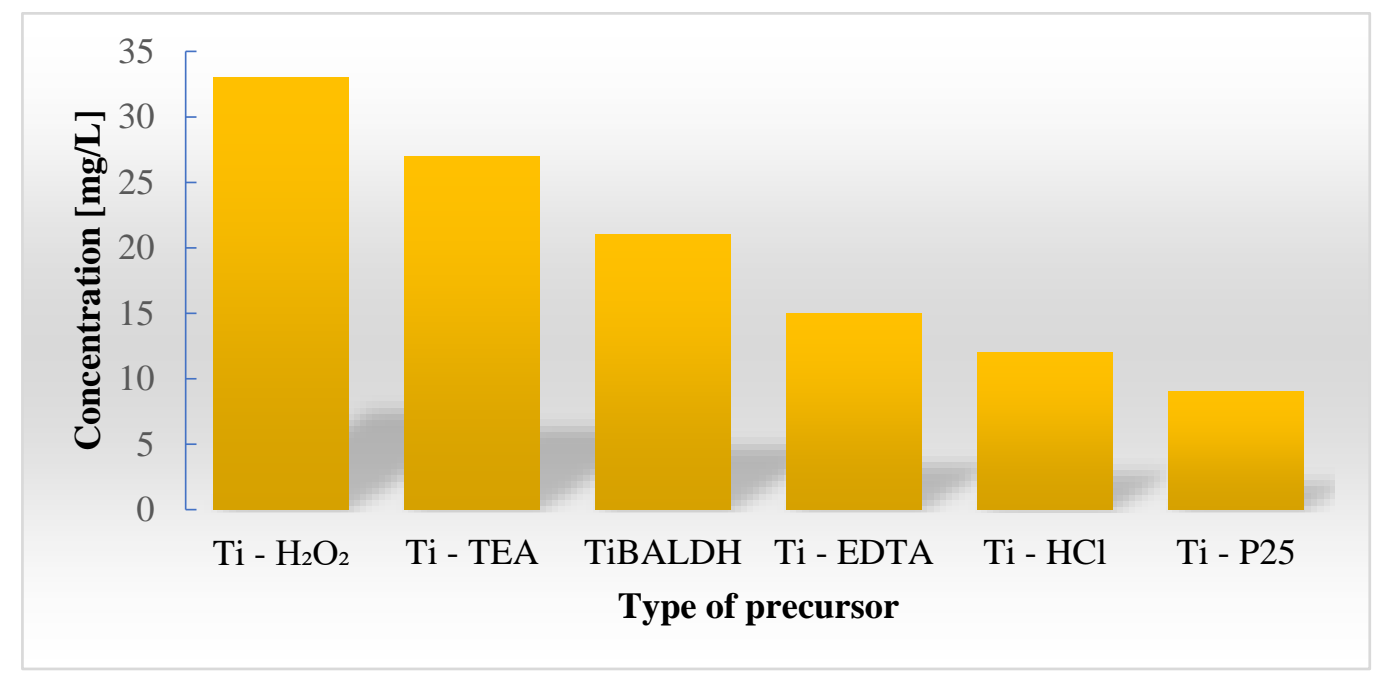

Figure 4. The limit of inhibition concentration depending on the type of titanium precursor used: Ti- $\mathrm{H}_{2} \mathrm{O}_{2}$ : Ti-hydrogen peroxide; Ti-TEA: Ti-triethanolamine; TiBALDH: titanium(IV) bis(ammonium lactate)dihydroxide; Ti-EDTA: Ti-ethylenediaminetetraacetic acid; $\mathrm{Ti}-\mathrm{HCl}$ : acid digested hydrolyzed titania; Ti-P25: titanium(IV) oxide.

Maeda et al. [59] noted that the effect of the titanium precursor on diatom cell growth differs with diatom species. When using TiBALDH as a precursor, the growth of Phaeodactylum tricornutum and Thalassiosira pseudonana was completely inhibited at $2.0 \mathrm{mM}$ TiBALDH, while the inhibition of $F$. solaris growth at the same concentration of TiBALDH was insignificant. Statistically significant inhibition of F. solaris cells growth occurred at $5.0 \mathrm{mM}$ TiBALDH, while in P. tricornutum and T. pseudonana, this occurred at $1.0 \mathrm{mM}$ and $0.5 \mathrm{mM}$ TiBALDH, respectively. According to Lang's research [60], the growth of T. weissflogii cells was inhibited by $2.0 \mathrm{mM}$ TiBLADH. 
Comparing the results of the studies on the incorporation of titanium into the diatom frustules, it can be seen that in each experiment there was an uneven distribution of titanium in the biosilica structure. It has been observed that a higher concentration of titanium is found near the pores than near the rib of the frustule. In addition, the amount of titanium incorporated into doped diatom frustules varies significantly between studies, even when using the same titanium ion precursor. In terms of the atomic percentage, Ti:Si, Jeffryes et al. [51] achieved the largest incorporation of $0.6 \%$, but when considering the concentration of titanium incorporated into diatom frustules (mM Ti), Maeda [59], Van Eynde [56], and Lang [60] all obtained higher values. The highest incorporated concentrations of titanium have been achieved using TiBALDH as a precursor. The results of titanium ion doping of diatomaceous biosilica are presented in Table 2.

Table 2. Summary of applied conditions for the cultivation of diatoms and the degree of incorporation of titanium into diatomaceous biosilica.

\begin{tabular}{cccccccc}
\hline Ref. & [19] & [55] & [56] & [57] & [58] & [59] & [60] \\
\hline Species & S. ac. & P. sp. & P. sp. & P. sp. & P. sp. Cos. sp. & F. sol. & T. weiss. \\
Precursor & $\mathrm{TiCl}_{4}$ & TiOSO $_{4}$ & TiBALDH & TiOSO $_{4}$ & TiOSO $_{4}$ & TiBALDH & TiBALDH \\
[Ti] [mM] & 10 & $0.0085-0.073$ & $0.0-0.56$ & 0.36 & $0.36-0.62$ & $0.25-20$ & $0.2-2.0$ \\
Ti:Si [\% atom] ${ }^{\text {a }}$ & 0.16 & 0.6 & 3.2 & 0.62 & 0.34 & 6.02 & 20 \\
Ti:Si [\%wt] & 0.6 & 2.3 & 10.4 & 2.37 & 0.93 & 10.6 & 34 \\
Method of Analysis $^{\text {ICP-MS }}$ & ICP-AES & ICP-MS & ICP-MS & EDS & ICP-AES & EDS \\
\hline
\end{tabular}

Notes: ${ }^{a}$ percentage by atomic of biosilica, ${ }^{b}$ percentage by weight of biosilica.

\subsection{Metabolic Insertion of Diatomaceous Biosilica with Germanium Ions}

There is a notable interest in imbedding nanoscale germanium into dielectric silica for optoelectronic applications. The controlled metabolic insertion of germanium into the silica frustule may produce a silicon/germanium nanocomposite imbedded into the exoskeleton microstructure. This Si-Ge nanocomposite could impart optoelectronic properties to this three-dimensional structure and at the same time controllably alter the microconstruction [62]. Early research into the germanium content in diatoms was focused on the toxicity of this element to diatom cells, and in particular its inhibitory effect on diatom frustule formation [73-75]. Lewin [73] noted that a content of only $1.0 \mu \mathrm{M}$ $\mathrm{GeO}_{2}$ significantly inhibited diatom growth, but the diatom species least sensitive to the inhibitory influence of $\mathrm{GeO}_{2}$ was P. tricornutum, the least silicified of the diatoms studied. It turned out that the inhibitory effect of $\mathrm{GeO}_{2}$ on diatom growth can be reduced by adding a correspondingly larger amount of $\mathrm{SiO}_{2}$ to the culture medium [73]. This conclusion is also in line with the assumption made by Richter [76] that diatoms show absolute demand for $\mathrm{SiO}_{2}$ in their growth phase. These results, and the chemical similarity of germanium and silicon, may suggest that the toxic effects of germanium involve inhibition of the formation of siliceous frustules of diatoms. The influence of germanium on metabolic processes of diatoms was demonstrated by Werner [74], who indicated that $\mathrm{Ge}(\mathrm{OH})_{4}$ completely inhibits the synthesis of chlorophyll in Cyclotella crypitica and, to a lesser extent, the synthesis of proteins. Similar conclusions were drawn by Azam [75], who showed that high concentrations of $\mathrm{Ge}(\mathrm{OH})_{4}$ inhibited the synthesis of chlorophyll and the photosynthetic carbon fixation by diatoms. Basharina et al. [19] also confirmed the toxic effects of germanium ions on diatom cells. The inclusion of germanium in the structure of diatom frustules resulted in various degrees of irregularity; the shape and thickness of frustules was altered, and something resembling an additional layer of silica could be detected. Mubarak Ali et al. [54] also demonstrated a positive relationship between the concentration of germanium in the culture medium of Stauroneis sp. strain and the degree of frustule aberration. Qin [52] reported that the metabolic insertion of germanium reduced the pore diameter in diatom frustules. However, Gale et al. [53] showed that metabolic doping of germanium resulted in smaller pores merging into larger ones, taking on the form of fissures. According to Basharina [19], the toxic 
effect of $\mathrm{Ge}(\mathrm{OH})_{4}$ may be associated with the premature condensation of $\mathrm{Si}(\mathrm{OH})_{4}$, which occurs without cellular control and causes solid silica deposits to be formed in the wrong places.

In the studies conducted on the metabolic insertion of germanium ions into diatomaceous biosilica, both two-stage [52-54,61,62] and one-stage diatom culture methods were used [3,19]. A summary of the diatom culture conditions and the degree of incorporation of germanium is presented in Table 3.

Table 3. Comparison of the applied conditions for diatoms culture and the degree of germanium incorporation into diatomaceous biosilica.

\begin{tabular}{|c|c|c|c|c|c|c|c|}
\hline Ref. & [3] & [19] & [52] & [53] & [54] & [61] & [62] \\
\hline Species & T. pseudo. ${ }^{\mathrm{a}}$ & S. $a c$. & N. frust. & P. sp. & Stauro. sp. ${ }^{b}$ & N. frust. ${ }^{\mathrm{c}}$ & P. sp. \\
\hline Culture Medium & No data & DM & LDM & LDM & $\mathrm{f} / 2$ & LDM & LDM \\
\hline $\operatorname{Lux}\left[\mu \mathrm{mol} / \mathrm{m}^{2} \cdot \mathrm{s}\right]$ & No data & $13-16$ & 150 & 150 & 164 & 125 & 50 \\
\hline $\mathrm{T}\left[{ }^{\circ} \mathrm{C}\right]$ & No data & 12 & 22 & 22 & No data & 22 & 22 \\
\hline $\mathrm{pH}$ & No data & 7.4 & $8.4-8.9$ & No data & No data & $8.2-8.4$ & 8.3 \\
\hline Process Type & I & I & II & II & II & II & II \\
\hline Precursor & $\mathrm{Ge}(\mathrm{OH})_{4}$ & $\mathrm{Na}_{2} \mathrm{GeO}_{3}$ & $\mathrm{GeO}_{2}$ & $\mathrm{GeO}_{2}$ & $\mathrm{GeO}_{2}$ & $\mathrm{Ge}(\mathrm{OH})_{4}$ & $\mathrm{GeO}_{2}$ \\
\hline$[\mathrm{Ge}]^{\mathrm{d}}[\mathrm{mM}]$ & 0.1 & 0.11 & 0.72 & 0.78 & 1.07 & 0.384 & 0.53 \\
\hline $\begin{array}{c}\mathrm{Ge}_{\text {incorp. }}{ }^{\mathrm{e}} \\
\text { Method of Analysis }\end{array}$ & $\begin{array}{l}0.42 \% \text { wt. } \\
\text { ICP-OES }\end{array}$ & $\begin{array}{l}5.1 \% \mathrm{~mol} \mathrm{Ge} / \mathrm{Si} \\
\text { ICP-MS }\end{array}$ & $\begin{array}{l}0.411 \% \text { wt. } \\
\text { ICP }\end{array}$ & $\begin{array}{l}0.965 \% \text { wt. } \\
\text { ICP }\end{array}$ & $\begin{array}{l}\text { No data } \\
\text { EDS }\end{array}$ & $\begin{array}{c}2.74 \mathrm{mg} \mathrm{Ge} / \mathrm{g} \text { of } \mathrm{DCW}^{\mathrm{f}} \\
\text { EDS }\end{array}$ & $\begin{array}{l}0.965 \% \text { wt. } \\
\text { ICP }\end{array}$ \\
\hline
\end{tabular}

Notes: ${ }^{\text {a }}$ Thalassiosira $p s e u d o n a n a,{ }^{b}$ Stauroneis sp., ${ }^{\mathrm{c}}$ Nitzschia frustulum,${ }^{\mathrm{d}}$ germanium content in the culture medium,

${ }^{\mathrm{e}}$ content of germanium incorporated into the diatom frustules, ${ }^{\mathrm{f}}$ dry cell weight.

In all works concerning the metabolic incorporation of germanium, its uneven distribution in the diatomaceous biosilica structure was detected [3,19,52-54,61,62]. Jeffryes [62] noticed that germanium was dispersed in silica in the form of clusters on both submicrometer and nanometer scales. Similar results were obtained by Mubarak Ali [54], indicating a lack of homogeneity in the distribution of germanium in diatom cells. The germanium content of the structure of the diatom frustule is around $1.0 \%$ by weight in all previously published works, which also show the dependence of the amount of germanium in the silica frustule on the initial Ge:Si concentration ratio in the culture medium (Figure 5).

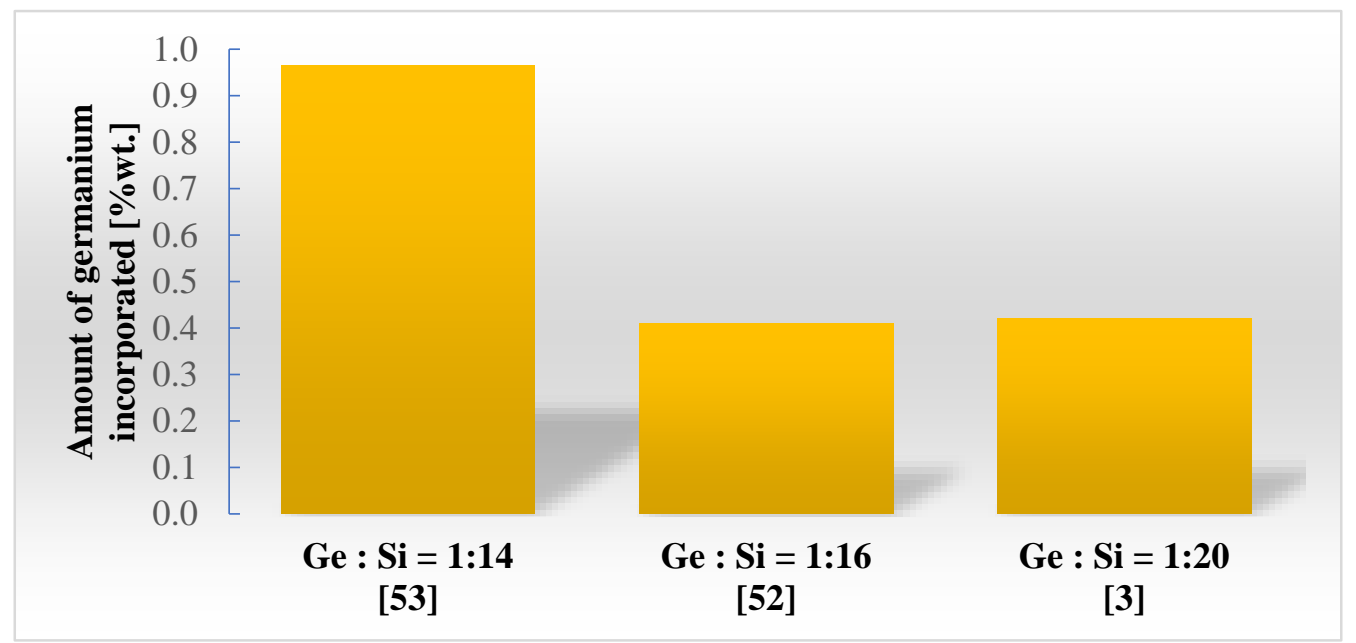

Figure 5. The dependence of the amount of germanium to silica frustule on the initial Ge:Si concentration ratio in the culture medium $[3,52,53]$.

Exceeding a certain limit of the Ge:Si concentration ratio (Ge:Si $=1: 100)$ causes a decrease in the incorporation of germanium into the frustules' structure [3]. A reduction in the degree of incorporation of germanium ions into the frustule is also visible when the Ge:Si ratio is lower than Ge:Si = 1:4.5 [61]. The most optimal Ge:Si ratio, which shows a linear relationship between the amount of germanium incorporated and the amount of biomass, is $\mathrm{Ge}: \mathrm{Si}=0.1$ [75]. 


\section{Metabolic Insertion of Other Metals and Semimetals Ions}

The works described above suggest that the concept of using the unique ability of diatom cultures to take up soluble metals and incorporate them into the structure of their frustules can also be applied to other metals, including nickel, europium, aluminum, zinc, iron, calcium, zirconium, and tin [19,63-67,69-71].

A summary of the diatom culture conditions used and the degree of incorporation of the indicated elements into diatomaceous biosilica in vivo is presented in Table 4 (calcium) and Table 5 (other elements).

Table 4. Summary of parameters for doping of diatomaceous biosilica with calcium ions.

\begin{tabular}{ccc}
\hline Ref. & {$[65]$} & {$[66]$} \\
\hline Species & T. weiss. & $\mathrm{Cos} . \mathrm{sp}$. \\
Precursor & $\mathrm{CaCl}_{2}$ & $\mathrm{CaCl}{ }_{2}$ \\
Culture Medium & $\mathrm{f} / 2$ & $\mathrm{f} / 2$ \\
Lux $\left[\mu \mathrm{mol} / \mathrm{m}^{2} \cdot \mathrm{s}\right]$ & No data & 246 \\
$\mathrm{~T}\left[{ }^{\circ} \mathrm{C}\right]$ & $18-22$ & 21 \\
$\mathrm{pH}$ & No data & No data \\
$\mathrm{Ca}_{\text {incorp }}{ }^{\mathrm{H}}[\% \mathrm{wt}]$ & 0.9 & No data \\
Method of Analysis & EDX & EDXS \\
\hline Note: ${ }^{\text {a }}$ content of calcium incorporated into the diatom frustules.
\end{tabular}

Table 5. Summary of results of doping diatoms with metal ions.

\begin{tabular}{|c|c|c|c|c|c|c|c|c|}
\hline \multirow[b]{2}{*}{ Ref. } & \multicolumn{2}{|c|}{$\mathrm{Zr} / \mathrm{Sn}$} & \multirow{2}{*}{$\frac{\mathbf{N i}}{[63]}$} & \multirow{2}{*}{$\begin{array}{c}\text { Al } \\
{[67]}\end{array}$} & \multicolumn{2}{|r|}{$\mathrm{Zn}$} & \multirow{2}{*}{$\begin{array}{c}\mathbf{F e} \\
{[70]}\end{array}$} & \multirow{2}{*}{$\begin{array}{c}\text { Eu } \\
{[71]}\end{array}$} \\
\hline & [19] & {$[64]$} & & & [69] & [70] & & \\
\hline Species & S. ac. & P. trico. ${ }^{a}$ & Cos. & S. tur. ${ }^{b}$ & S. hanz. ${ }^{c}$ & T. pseudo. & T. pseudo. & Navi. sp. ${ }^{\mathrm{d}}$ \\
\hline Culture Medium & $\mathrm{DM}$ & Aquil & Alga-Gro & ASW & CHU-10 & $\mathrm{f} / 2$ & $\mathrm{f} / 2$ & "Ningbo 3" \\
\hline $\operatorname{Lux}\left[\mu \mathrm{mol} / \mathrm{m}^{2} * \mathrm{~s}\right]$ & $13-16$ & No data & No data & 82 & 50 & 120 & 120 & 246 \\
\hline $\mathrm{T}\left[{ }^{\circ} \mathrm{C}\right]$ & 12 & 19 & 22 & 18 & 20 & $20-22$ & $20-22$ & 25 \\
\hline $\mathrm{pH}$ & 7.4 & 9 & No data & $8.0-8.2$ & 6.4 & $7.2-8.3$ & 8.0 & No data \\
\hline Process Type & I & I & I & I & II & II & II & II \\
\hline Precursor & $\mathrm{ZrCl}_{4}$ & $\mathrm{ZrOCl}_{2} \cdot 8 \mathrm{H}_{2} \mathrm{O}$ & $\mathrm{NiSO}_{4}$ & $\mathrm{AlCl}_{3}$ & Zn-EDTA & Zn-EDTA & Fe-EDTA & $\mathrm{Eu}\left(\mathrm{NO}_{3}\right)_{3} \cdot 6 \mathrm{H}_{2} \mathrm{O}$ \\
\hline$X_{\text {incorp. }}{ }^{\mathbf{e}}$ & $\begin{array}{c}3.4 \% \mathrm{~mol} \mathrm{Zr} / \mathrm{Si} \\
0.91 \% \mathrm{~mol} \mathrm{Sn} / \mathrm{Si}\end{array}$ & No data & $\sim 0.1 \%$ wag & No data & No data & $\begin{array}{c}2-5 \cdot 10^{17} \mathrm{~mol} \\
\mathrm{Zn} / \text { cell } \cdot \text { day }\end{array}$ & No data & No data \\
\hline Method of Analysis & ICP-MS & EDX & EDX & ICP-OES & ICP-MS & GFAAS & GFAAS & XRD \\
\hline
\end{tabular}

\subsection{Doping of Biosilica with Aluminium Ions}

Machill et al. [67] conducted research on the introduction of aluminum into the frustule structure of the marine diatom, Stephanopyxis turris, using artificial seawater containing different concentrations of aluminum $(10.5,42.5,105.5$, and $1055 \mu \mathrm{m})$ in the form of $\mathrm{AlCl}_{3}$. These concentrations correspond to Al:Si mass ratios of 1:10, 1:2.5, 1:1, and 10:1 respectively. It was observed that a concentration of $10.5 \mu \mathrm{m}$ avoids uncontrolled aluminum precipitation. A SEM analysis performed to assess the influence of aluminum on the morphology of diatom frustules did not show any significant morphological differences compared with diatoms grown without aluminum in the culture medium. The same size and structure of frustules were detected for both alumina-enriched and natural diatom samples. The incorporation of aluminum into biosilica was detected by ICP-OES analysis of extracted frustules. Quantification has shown that the amount of aluminum embedded in frustules increased rapidly in a medium enriched with aluminum, although no value for the content of aluminum is given. It was observed that the greatest ratio of Al:Si obtained was 1:15. Diatomaceous biosilica doped with aluminum ions can be very valuable material used in catalysis due to its high catalytic activity [51]. 


\subsection{Doping of Biosilica with Nickel Ions}

Townley et al. [63] presented the results of studies on doping Coscinodiscus wailesii cells with nickel ions to modify the optical properties of their frustules. Selected diatom species were cultured in sterile filtered seawater containing an Alga-Gro medium with nickel sulphate added at 5.0, 1.0, 0.5, and $0.1 \mathrm{mg} / \mathrm{L}$. It was observed that the maximum concentration of nickel, which had no significant effect on the growth of diatoms, was $0.5 \mathrm{mg} / \mathrm{L}$.

The SEM analysis of diatoms enriched in nickel showed that the pores in their frustules were more irregular, larger, and less uniform in shape. Studies of the cytoplasmic morphology of $C$. wailesii cultivated in the presence of nickel sulphate showed an interruption of thylakoid stacks and swelling of mitochondria. As the nickel concentration in the culture medium increased, the photoluminescence of silica frustules was also extinguished. The nickel content in the diatoms frustules was about $0.1 \%$ by weight and was confirmed by the EDX method. Diatomaceous biosilica doped with nickel ions can be used in biotechnology applications due to its unique optical properties.

\subsection{Biosilica Doping with Europium Ions}

Silicate-based phosphors are promising luminescent materials because of their chemical stability, moisture resistance, and low cost. These materials can be used in various display technologies, such as fluorescent lamps, plasma display panels, field emission displays, and cathode-ray tubes. Zhang et al. [71] published results on the doping of diatomaceous biosilica with europium. Doping was carried out by culturing Navicula sp. with the addition of europium hexavalent nitrate (Eu $\left.\left(\mathrm{NO}_{3}\right)_{3} \cdot 6 \mathrm{H}_{2} \mathrm{O}\right)$ in the molar ratio 1:4 Eu:Si. The culture was carried out for $96 \mathrm{~h}$, then the diatom cells were extracted with ethanol to remove the alcohol-soluble organic material, and the solid residues were heat annealed in air at $1000{ }^{\circ} \mathrm{C}$. An XRD analysis showed the presence of europium in the form of $\mathrm{Eu}_{2} \mathrm{O}_{3}$ and $\mathrm{Eu}_{2} \mathrm{SiO}_{5}$. Europium-doped biosilica exhibited photoluminescent properties with red light emission $(614 \mathrm{~nm})$ and excitation at $394 \mathrm{~nm}$ corresponding to the wavelength of LED emission.

\subsection{Doping of Biosilica with Calcium Ions}

Leone et al. [65] recently published results on the doping of diatomaceous biosilica with calcium cations for biomedical materials. The idea for this work was based on the knowledge that fibroblasts and osteoblasts grow very well on silica or ceramic substrates, and the presence of calcium ions stimulates the growth of the cells. Calcium-doped diatomaceous biosilica was obtained during the cultivation of Thalassiosira weissflogii in autoclaved and ultrafiltered sea water at a controlled temperature of $18-22{ }^{\circ} \mathrm{C}$, with the addition of calcium in the form of $\mathrm{CaCl}_{2}(14 \mathrm{mM})$ to the culture medium.

SEM showed that the addition of calcium to diatom culture does not affect their shape and structure. FTIR showed that even though the calcium is not covalently bonded with the biosilica obtained, it remains in the frustules despite the action of $30 \%$ hydrogen peroxide to remove organic matter from diatom cells. The detected content of calcium in the doped frustules was in the range of $0.9 \pm 0.05 \%$ weight. Cell viability studies also confirmed that calcium-doped biosilica can serve as an effective substrate for the growth of fibroblasts and osteoblasts with possible applications in regenerative medicine.

$\mathrm{Li}$ et al. [66] also investigated the calcium ion doping of diatoms. Coscinodiscus sp. were cultured in ultrafiltered and autoclaved sea water enriched with a f/2 Guillard medium at $21^{\circ} \mathrm{C}$, and calcium inclusion in diatom frustules was achieved by introducing $\mathrm{CaCl}_{2}$ calcium chloride into the culture medium at $0.125,0.25,0.50,1.0$, and $2.0 \mathrm{mM}$.

The presence of calcium ions in the structure of diatom frustules was confirmed by XRD and EDXS, but no specific values were provided. Similar to Leone [65], the presence of calcium ions in the culture medium in Li et al. [62] did not cause any significant changes in the morphology of diatoms, and the authors indicated that the material obtained could be used as a haemostatic. Detailed data on the conditions of doping of diatomaceous biosilica with calcium ions are given in Table 4 . 


\subsection{Doping of Biosilica with Zirconium and Tin Ions}

The influence of zirconium and tin on the growth, morphology, and chemical composition of the freshwater diatom Synedra acus was studied by Basharina et al. [19]. Microincubators containing a culture medium with $10 \mathrm{mM} \mathrm{Na}_{2} \mathrm{SiO}_{3}$ and $10 \mathrm{mM} \mathrm{Na}_{2} \mathrm{SnO}_{3}$ or $\mathrm{ZrCl}_{4}$ were used. It was noted that doping with zirconium and tin ions caused a slight decrease in growth rate, irregularity of frustules, and a decrease in mechanical strength of the frustules. Analysis showed the presence of $3.4 \% \mathrm{~mol} \mathrm{Zr} / \mathrm{Si}$ and $0.91 \% \mathrm{~mol} \mathrm{Sn} / \mathrm{Si}$ in the diatom biomass, and $0 \% \mathrm{Zr}$ and $0.13 \% \mathrm{Sn}$ in the purified diatomaceous biosilica.

In order to obtain nanoporous composites of diatom- $\mathrm{ZrO}_{2}$, Gannavarapu et al. [64] conducted studies on the culture of the species Phaeodactylum tricornutum using artificial sea water at $\mathrm{pH}=9$ with the addition of $0.8 \mathrm{mM} \mathrm{ZrOCl}_{2} \cdot 8 \mathrm{H}_{2} \mathrm{O}$ as a culture medium. The presence of $\mathrm{ZrO}_{2}$ zirconium oxides on the surface of Phaeodactylum tricornutum frustules was confirmed by EDX analysis. A significant decrease in the size of diatom cells was also observed. The obtained composite has been successfully tested as an electrochemical sensor for the detection of methyl parathion-an organophosphorus pesticide.

\subsection{Biosilica Doping with Zinc and Iron Oons}

In order to verify that diatoms were able to incorporate significant amounts of zinc and iron, Ellwood and Hunter [70] grew the marine diatom Thalassiosira pseudonana in sea water with the addition of $\mathrm{Zn}$ or Fe salts. A positive relationship was observed between the concentration of free $\mathrm{Zn}^{2+}$ and the growth rate of T. pseudonana. It was also found that limiting access to free $\mathrm{Zn}^{2+}$ caused a decrease in cell size in T. pseudonana in comparison with those in the free $\mathrm{Zn}^{2+}$ replete medium. An analysis of the chemical composition of the biosilica obtained confirmed the inclusion of zinc and iron ions into the structure of the diatom frustules. In the case of zinc ion incorporation, it was found that the amount of $\mathrm{Zn}^{2+}$ uptake into the diatom was directly related to the amount of zinc absorbed by the diatom diatom $\left(2-5 \times 10^{-17} \frac{\mathrm{mol}}{\text { cell } \times \text { day }}\right)$, which in turn was directly related to the concentration of free $\mathrm{Zn}^{2+}$ in the culture medium. The relationship between $\mathrm{Zn} / \mathrm{Si}$ and free $\mathrm{Zn}^{2+}$ suggests that the $\mathrm{Zn}$ content of diatom shells may be useful in reconstructing changes in oceanic concentration of free $\mathrm{Zn}^{2+}$. In the case of iron ion incorporation, no direct proportional relationship between the incorporated iron content and its concentration in the culture medium was detected. Moreover, no specific value was determined for the amount of iron incorporated into the diatom cell.

The studies reported in Ellwood and Hunter [70] were continued by Jaccard et al. [69]. They cultivated the freshwater diatom Stephanodiscus hantzschii (UTCC 267) in a modified medium CHU-10 [77] with the addition of the Zn-EDTA complex, containing $10^{-10.6}-10^{-7.6} \mathrm{M}$ zinc ions. The presence of zinc ions in the structure of diatom frustules was confirmed by ICP-MS. No value was given for the amount of zinc incorporated into the diatom frustules, but it was found that the highest degree of zinc ion incorporation was achieved at a concentration of $10^{-8.5} \mathrm{M} \mathrm{Zn}^{2+}$.

The conditions used to grow diatoms and the degree of metabolic insertion of elements $(\mathrm{Al}, \mathrm{Ni}$, $\mathrm{Eu}, \mathrm{Zr}, \mathrm{Sn}, \mathrm{Zn}, \mathrm{Fe}$ ) into diatomaceous biosilica are summarized in Table 5.

\section{Conclusions}

This analysis of the limited research available on the metabolic insertion of elements into the structured diatomaceous biosilica indicates the emergence of a new trend in synthesis methods for next-generation functional materials. This new approach harnesses the ability of microorganisms to act as microtechnologists for the synthesis of smart materials, in particular the diatoms in synthesizing new silica materials with desirable properties.

There is evidence that many factors, such as the type of precursor, chemical composition and $\mathrm{pH}$ of the culture medium, temperature, illumination, and aeration, can significantly impact the process of metabolic insertion into diatomaceous biosilica, the growth and development of diatom cells, and the structure and morphology of the frustules. Therefore, there is scope for optimizing the 
process of metabolic insertion by manipulating these factors (e.g., by changing the Ge:Si ratio in the culture medium). A further aspect is the variation in the influence of different factors and doping elements on different diatom species, and therefore the choice of diatom species is also crucial. Finally, there is further potential for metabolic insertion techniques by using a genetic modification of diatom cells $[20,78]$ in order to give them specific abilities for selective metabolic insertion of selected elements.

Author Contributions: Conceptualization, M.S.; Software, W.B. and I.W.; Writing, W.B. and M.S.; Original Draft Preparation, W.B. and I.W.; Writing-Review \& Editing, W.B., M.S., I.W., P.D., A.W. and B.B.; Funding Acquisition, B.B. and A.W. All authors have read and agreed to the published version of the manuscript.

Funding: This work was supported by the project "Advanced biocomposites for tomorrow's economy BIOG-NET" carried out within the TEAM-NET programme of the Foundation for Polish Science co-financed by the European Union under the European Regional Development Fund.

Conflicts of Interest: The authors declare no conflict of interest.

\section{References}

1. Gross, M. The mysteries of the diatoms. Curr. Biol. 2012, 22, 581-585. [CrossRef] [PubMed]

2. Görlich, S.; Pawolski, D.; Zlotnikov, I.; Kröger, N. Control of biosilica morphology and mechanical performance by the conserved diatom gene Silicanin-1. Commun. Biol. 2019, 2, 245. [CrossRef] [PubMed]

3. Davis, A.K.; Hildebrand, M. A self-propagating system for Ge incorporation into nanostructured silica. Chem. Commun. 2008, 4495-4497. [CrossRef] [PubMed]

4. Zhang, D.Y.; Wang, Y.; Cai, J.; Pan, J.F.; Jiang, X.G.; Jiang, Y.G. Bio-manufacturing technology based on diatom micro- and nanostructure. Chin. Sci. Bull. 2012, 57, 3836-3849. [CrossRef]

5. Mann, D.G.; Vanormelingen, P. An inordinate fondness the number, distributions, and origins of diatom species. J. Eukaryot. Microbiol. 2013, 60, 414-420. [CrossRef] [PubMed]

6. Wang, J.K.; Seibert, M. Prospects for commercial production of diatoms. Biotechnol. Biofuels 2017, 10, 1-13. [CrossRef] [PubMed]

7. Popovich, C.A.; Pistonesi, M.; Hegel, P.; Constenla, D.; Bielsa, G.B.; Martín, L.A.; Damiani, M.C.; Leonardi, P.I. Unconventional alternative biofuels: Quality assessment of biodiesel and its blends from marine diatom Navicula cincta. Algal Res. 2019, 39, 101438. [CrossRef]

8. Fu, W.; Nelson, D.R.; Mystikou, A.; Daakour, S.; Salehi-Ashtiani, K. Advances in microalgal research and engineering development. Curr. Opin. Biotechnol. 2019, 59, 157-164. [CrossRef]

9. Sasirekha, R.; Sheena, T.S.; Anitha, R.; Santhanam, P.; Kulandaivel, J. Characterizations and analysis of genus Amphora diatom frustules: A promising biomaterial. Bioinspired Biomim. Nanobiomater. 2019, 8, 224-230. [CrossRef]

10. Panwar, V.; Dutta, T. Diatom Biogenic Silica as a Felicitous Platform for Biochemical Engineering: Expanding Frontiers. ACS Appl. Bio Mater. 2019, 2, 2295-2316. [CrossRef]

11. Maher, S.; Maher, S.; Aw, M.S.; Losic, D. Diatom Silica for Biomedical Applications. Diatoms Fundam. Appl. 2019, 511-536. [CrossRef]

12. Vinayak, V.; Joshi, K.B.; Sarma, P.M. Diafuel ${ }^{\mathrm{TM}}$ (Diatom Biofuel) vs Electric Vehicles, a Basic Comparison: A High Potential Renewable Energy Source to Make India Energy Independent. In Diatoms: Fundamentals and Applications; Wiley: Hoboken, NJ, USA, 2019; pp. 537-582.

13. Gordon, R.; Merz, C.R.; Gurke, S.; Schoefs, B. Bubble Farming: Scalable Microcosms for Diatom Biofuel and the Next Green Revolution. Diatoms Fundam. Appl. 2019, 583-654. [CrossRef]

14. Vinayak, V.; Gautam, S. Diatoms in Forensics: A Molecular Approach to Diatom Testing in Forensic Science. Diatoms Fundam. Appl. 2019, 435-470. [CrossRef]

15. Gordon, R.; Drum, R.W. The Chemical Basis of Diatom Morphogenesis. Int. Rev. Cytol. 1994, 150, 243-372. [CrossRef]

16. Gordon, R.; Losic, D.; Tiffany, M.A.; Nagy, S.S.; Sterrenburg, F.A.S. The Glass Menagerie: Diatoms for novel applications in nanotechnology. Trends Biotechnol. 2009, 27, 116-127. [CrossRef]

17. Bozarth, A.; Maier, U.G.; Zauner, S. Diatoms in biotechnology: Modern tools and applications. Appl. Microbiol. Biotechnol. 2009, 82, 195-201. [CrossRef]

18. Nassif, N.; Livage, J. From diatoms to silica-based biohybrids. Chem. Soc. Rev. 2011, 40, 849-859. [CrossRef] 
19. Basharina, T.N.; Danilovtseva, E.N.; Zelinskiy, S.N.; Klimenkov, I.V.; Likhoshway, Y.V.; Annenkov, V.V. The Effect of Titanium, Zirconium and Tin on the Growth of Diatom Synedra acus and Morphology of Its Silica Valves. Silicon 2012, 4, 239-249. [CrossRef]

20. Mishra, M.; Arukha, A.P.; Bashir, T.; Yadav, D.; Prasad, G.B.K.S. All new faces of diatoms: Potential source of nanomaterials and beyond. Front. Microbiol. 2017, 8, 1-8. [CrossRef]

21. Athanasakoglou, A.; Kampranis, S.C. Diatom isoprenoids: Advances and biotechnological potential. Biotechnol. Adv. 2019, 37. [CrossRef]

22. Martínez-Carmona, M.; Gun'ko, Y.K.; Vallet-Regí, M. Mesoporous silica materials as drug delivery: "the nightmare" of bacterial infection. Pharmaceutics 2018, 10, 279. [CrossRef] [PubMed]

23. Uthappa, U.T.; Brahmkhatri, V.; Sriram, G.; Jung, H.Y.; Yu, J.; Kurkuri, N.; Aminabhavi, T.M.; Altalhi, T.; Neelgund, G.M.; Kurkuri, M.D. Nature engineered diatom biosilica as drug delivery systems. J. Control. Release 2018, 281, 70-83. [CrossRef] [PubMed]

24. De Tommasi, E.; Gielis, J.; Rogato, A. Diatom Frustule Morphogenesis and Function: A Multidisciplinary Survey. Mar. Genom. 2017, 35, 1-18. [CrossRef] [PubMed]

25. De Stefano, L.; Rotiroti, L.; De Stefano, M.; Lamberti, A.; Lettieri, S.; Setaro, A.; Maddalena, P. Marine diatoms as optical biosensors. Biosens. Bioelectron. 2009, 24, 1580-1584. [CrossRef] [PubMed]

26. Anderson, N.J. Miniview: Diatoms, temperature and climatic change. Eur. J. Phycol. 2000, 35, 307-314. [CrossRef]

27. Townley, H.E.; Parker, A.R.; White-Cooper, H. Exploitation of diatom frustules for nanotechnology: Tethering active biomolecules. Adv. Funct. Mater. 2008, 18, 369-374. [CrossRef]

28. De Stefano, L.; Maddalena, P.; Moretti, L.; Rea, I.; Rendina, I.; De Tommasi, E.; Mocella, V.; De Stefano, M. Nano-biosilica from marine diatoms: A brand new material for photonic applications. Superlattices Microstruct. 2009, 46, 84-89. [CrossRef]

29. He, J.; Chen, D.; Li, Y.; Shao, J.; Xie, J.; Sun, Y.; Yan, Z.; Wang, J. Diatom-templated $\mathrm{TiO}_{2}$ with enhanced photocatalytic activity: Biomimetics of photonic crystals. Appl. Phys. A Mater. Sci. Process. 2013, 113, 327-332. [CrossRef]

30. Nowak, A.P.; Sprynskyy, M.; Brzozowska, W.; Lisowska-Oleksiak, A. Electrochemical behavior of a composite material containing 3D-structured diatom biosilica. Algal Res. 2019, 41, 101538. [CrossRef]

31. Norberg, A.N.; Wagner, N.P.; Kaland, H.; Vullum-Bruer, F.; Svensson, A.M. Silica from diatom frustules as anode material for Li-ion batteries. RSC Adv. 2019, 9, 41228-41239. [CrossRef]

32. Toster, J.; Iyer, K.S.; Xiang, W.; Rosei, F.; Spiccia, L.; Raston, C.L. Diatom frustules as light traps enhance DSSC efficiency. Nanoscale 2013, 5, 873-876. [CrossRef] [PubMed]

33. Wang, Y.; Cai, J.; Jiang, Y.; Jiang, X.; Zhang, D. Preparation of biosilica structures from frustules of diatoms and their applications: Current state and perspectives. Appl. Microbiol. Biotechnol. 2013, 97, 453-460. [CrossRef] [PubMed]

34. Chandrasekaran, S.; Sweetman, M.J.; Kant, K.; Skinner, W.; Losic, D.; Nann, T.; Voelcker, N.H. Silicon diatom frustules as nanostructured photoelectrodes. Chem. Commun. 2014, 50, 10441-10444. [CrossRef] [PubMed]

35. Huang, D.R.; Jiang, Y.J.; Liou, R.L.; Chen, C.H.; Chen, Y.A.; Tsai, C.H. Enhancing the efficiency of dye-sensitized solar cells by adding diatom frustules into $\mathrm{TiO}_{2}$ working electrodes. Appl. Surf. Sci. 2015, 347, 64-72. [CrossRef]

36. Lin, K.B.; Shen, T.W.; Su, Y.H. Silicon-Based Solar Cells: Emergent Upconversion Sustainable Micro-Optical Trapping Device (Part. Part. Syst. Charact. 7/2019). Part. Part. Syst. Charact. 2019, 36, 1970017. [CrossRef]

37. Jeffryes, C.; Campbell, J.; Li, H.; Jiao, J.; Rorrer, G. The potential of diatom nanobiotechnology for applications in solar cells, batteries, and electroluminescent devices. Energy Environ. Sci. 2011, 4, 3930-3941. [CrossRef]

38. Bao, Z.; Weatherspoon, M.R.; Shian, S.; Cai, Y.; Graham, P.D.; Allan, S.M.; Ahmad, G.; Dickerson, M.B.; Church, B.C.; Kang, Z.; et al. Chemical reduction of three-dimensional silica micro-assemblies into microporous silicon replicas. Nature 2007, 446, 172-175. [CrossRef]

39. Kroth, P. Molecular biology and the biotechnological potential of diatoms. Adv. Exp. Med. Biol. 2007, 616, 23-33. [CrossRef]

40. Leonardo, S.; Prieto-Simón, B.; Campàs, M. Past, present and future of diatoms in biosensing. TrAC Trends Anal. Chem. 2016, 79, 276-285. [CrossRef]

41. Umemura, K.; Gao, Y.; Nishikawa, T. Preparation of photocatalyst using diatom frustules by liquid phase deposition method. J. Nanosci. Nanotechnol. 2010, 10, 4883-4888. [CrossRef] 
42. Huang, W.; Daboussi, F. Genetic and metabolic engineering in diatoms. Philos. Trans. R. Soc. B Biol. Sci. 2017, 372. [CrossRef] [PubMed]

43. Yang, W.; Lopez, P.J.; Rosengarten, G. Diatoms: Self assembled silica nanostructures, and templates for bio/chemical sensors and biomimetic membranes. Analyst 2011, 136, 42-53. [CrossRef] [PubMed]

44. Irimia-Vladu, M.D.; Glowacki, E.S.; Sariciftci, N.; Bauer, S.; Ragni, R.; Cicco, S.R.; Vona, D.; Farinola, G.M. Nanostructured Silica from Diatoms Microalgae: Smart Materials for Photonics and Electronics. Green Mater. Electron. 2017, 287-313. [CrossRef]

45. Terracciano, M.; De Stefano, L.; Rea, I. Diatoms green nanotechnology for biosilica-based drug delivery systems. Pharmaceutics 2018, 10, 242. [CrossRef] [PubMed]

46. Ramachandra, T.V.; Mahapatra, D.M.; Karthick, B.; Gordon, R. Milking diatoms for sustainable energy: Biochemical engineering versus gasoline-secreting diatom solar panels. Ind. Eng. Chem. Res. 2009, 48, 8769-8788. [CrossRef]

47. Zglobicka, I.; Chmielewska, A.; Topal, E.; Kutukova, K.; Gluch, J.; Krüger, P.; Kilroy, C.; Swieszkowski, W.; Kurzydlowski, K.J.; Zschech, E. 3D Diatom-Designed and Selective Laser Melting (SLM) Manufactured Metallic Structures. Sci. Rep. 2019, 9, 1-9. [CrossRef]

48. Bandara, T.M.W.J.; Furlani, M.; Albinsson, I.; Wulff, A.; Mellander, B.E. Diatom frustules enhancing the efficiency of gel polymer electrolyte based dye-sensitized solar cells with multilayer photoelectrodes. Nanoscale Adv. 2020, 2, 199-209. [CrossRef]

49. Kröger, N.; Dubey, N.C.; Kumari, E. CHAPTER 6: Immobilization of Proteins on Diatom Biosilica. In RSC Nanoscience and Nanotechnology; Royal Society of Chemistry: London, UK, January 2018; Volume 2018, pp. 126-149, ISBN 9781782624585.

50. Ragni, R.; Cicco, S.; Vona, D.; Leone, G.; Farinola, G.M. Biosilica from diatoms microalgae: Smart materials from bio-medicine to photonics. J. Mater. Res. 2017, 32, 279-291. [CrossRef]

51. Köhler, L.; Machill, S.; Werner, A.; Selzer, C.; Kaskel, S.; Brunner, E. Are Diatoms “Green” Aluminosilicate Synthesis Microreactors for Future Catalyst Production? Molecules 2017, 22, 2232. [CrossRef]

52. Qin, T.; Gutu, T.; Chang, C.H.; Jiao, J.; Rorrer, G.L. Biological fabrication of photoluminescent nanocomb structures by metabolic incorporation of germanium into the biosilica of the diatom Nitzschia frustulum. ACS Nano 2008, 2, 1296-1304. [CrossRef]

53. Gale, D.K.; Jeffryes, C.; Gutu, T.; Jiao, J.; Chang, C.H.; Rorrer, G.L. Thermal annealing activates amplified photoluminescence of germanium metabolically doped in diatom biosilica. J. Mater. Chem. 2011, 21, 10658-10665. [CrossRef]

54. Ali, D.M.; Divya, C.; Gunasekaran, M.; Thajuddin, N. Biosynthesis and Characterization of Silicon-Germanium Oxide Nanocomposite By Diatom. Dig. J. Nanomater. Biostruct. 2011, 6, 117-120.

55. Jeffryes, C.; Gutu, T.; Jiao, J.; Rorrer, G.L. Metabolic Insertion of Nanostructured $\mathrm{TiO}_{2}$ into the Patterned Biosilica of the Diatom. ACS Nano 2008, 2, 2103-2112. [CrossRef] [PubMed]

56. Van Eynde, E.; Hu, Z.Y.; Tytgat, T.; Verbruggen, S.W.; Watté, J.; Van Tendeloo, G.; Van Driessche, I.; Blust, R.; Lenaerts, S. Diatom silica-titania photocatalysts for air purification by bio-accumulation of different titanium sources. Environ. Sci. Nano 2016, 3, 1052-1061. [CrossRef]

57. Chauton, M.S.; Skolem, L.M.B.; Olsen, L.M.; Vullum, P.E.; Walmsley, J.; Vadstein, O. Titanium uptake and incorporation into silica nanostructures by the diatom Pinnularia sp. (Bacillariophyceae). J. Appl. Phycol. 2015, 27, 777-786. [CrossRef] [PubMed]

58. Skolem, L.M.B. Biosynthesis and Characterization of Ti-Doped Silica-Based Nanostructures Formed by the Diatoms Pinnularia sp. and Coscinodiscus wailesii; Norwegian University of Science and Technology: Trondheim, Norway, 2011; Volume 801.

59. Maeda, Y.; Niwa, Y.; Tang, H.; Kisailus, D.; Yoshino, T.; Tanaka, T. Development of Titania-Integrated Silica Cell Walls of the Titanium-Resistant Diatom, Fistulifera solaris. ACS Appl. Bio Mater. 2018, 1, 2021-2029. [CrossRef]

60. Lang, Y.; Monte, F.D.; Rodriguez, B.J.; Dockery, P.; Finn, D.P.; Pandit, A. Integration of $\mathrm{TiO}_{2}$ into the diatom Thalassiosira weissflogii during frustule synthesis. Sci. Rep. 2013, 3, 1-11. [CrossRef]

61. Rorrer, G.L.; Chang, C.H.; Liu, S.H.; Jeffryes, C.; Jiao, J.; Hedberg, J.A. Biosynthesis of silicon-germanium oxide nanocomposites by the marine diatom Nitzschia frustulum. J. Nanosci. Nanotechnol. 2005, 5, 41-49. [CrossRef] 
62. Jeffryes, C.; Gutu, T.; Jiao, J.; Rorrer, G.L. Two-stage photobioreactor process for the metabolic insertion of nanostructured germanium into the silica microstructure of the diatom Pinnularia sp. Mater. Sci. Eng. C 2008, 28, 107-118. [CrossRef]

63. Townley, H.E.; Woon, K.L.; Payne, F.P.; White-Cooper, H.; Parker, A.R. Modification of the physical and optical properties of the frustule of the diatom Coscinodiscus wailesii by nickel sulfate. Nanotechnology 2007, 18, 14-19. [CrossRef]

64. Gannavarapu, K.P.; Ganesh, V.; Thakkar, M.; Mitra, S.; Dandamudi, R.B. Nanostructured Diatom-ZrO $\mathrm{Zr}_{2}$ composite as a selective and highly sensitive enzyme free electrochemical sensor for detection of methyl parathion. Sens. Actuators B Chem. 2019, 288, 611-617. [CrossRef] [PubMed]

65. Leone, G.; Vona, D.; Lo Presti, M.; Urbano, L.; Cicco, S.; Gristina, R.; Palumbo, F.; Ragni, R.; Farinola, G.M. $\mathrm{Ca}^{2+}$-in vivo doped biosilica from living Thalassiosira weissflogii diatoms: Investigation on Saos-2 biocompatibility. Mater. Res. Soc. 2017, 2, 1047-1058. [CrossRef]

66. Li, J.; Han, J.; Sun, Q.; Wang, Y.; Mu, Y.; Zhang, K.; Dou, X.; Kong, M.; Chen, X.; Feng, C. Biosynthetic calcium-doped biosilica with multiple hemostatic properties for hemorrhage control. J. Mater. Chem. B 2018, 6, 7834-7841. [CrossRef] [PubMed]

67. Machill, S.; Kohler, L.; Ueberlein, S.; Hedrich, R.; Kunaschk, M.; Paasch, S.; Schulze, R.; Brunner, E. Analytical studies on the incorporation of aluminium in the cell walls of the marine diatom Stephanopyxis turris. BioMetals 2013, 26, 141-150. [CrossRef] [PubMed]

68. Gehlen, M.; Beck, L.; Calas, G.; Flank, A.M.; Van Bennekom, A.J.; Van Beusekom, J.E.E. Unraveling the atomic structure of biogenic silica: Evidence of the structural association of $\mathrm{Al}$ and $\mathrm{Si}$ in diatom frustules. Geochim. Cosmochim. Acta 2002, 66, 1601-1609. [CrossRef]

69. Jaccard, T.; Ariztegui, D.; Wilkinson, K.J. Incorporation of zinc into the frustule of the freshwater diatom Stephanodiscus hantzschii. Chem. Geol. 2009, 265, 381-386. [CrossRef]

70. Ellwood, M.J.; Hunter, K.A. The incorporation of zinc and iron into the frustule of the marine diatom Thalassiosira pseudonana. Limnol. Oceanogr. 2000, 45, 1517-1524. [CrossRef]

71. Zhang, G.; Jiang, W.; Wang, L.; Liao, X.; Liu, P.; Deng, X.; Li, J. Preparation of silicate-based red phosphors with a patterned nanostructure via metabolic insertion of europium in marine diatoms. Mater. Lett. 2013, 110, 253-255. [CrossRef]

72. Rorrer, G.L. CHAPTER 4: Functionalization of Frustules from Diatom Cell Culture for Optoelectronic Properties. In RSC Nanoscience and Nanotechnology; Royal Society of Chemistry: London, UK, January 2018; Volume 2018, pp. 79-110, ISBN 9781782624585.

73. Lewin, J. Silicon Metabolism in Diatoms: 5. Germanium Dioxide, a Specific Inhibitor of Diatom Growth. Phycologia 1966, 6, 1-12. [CrossRef]

74. Werner, D. Hemmung der Chlorophyllsynthese und der NADP+-abhängigen Glycerinaldehyd-3-Phosphat-Dehydrogenase durch Germaniumsäure bei Cyclotella cryptica. Arch. Mikrobiol. 1967, 57, 51-60. [CrossRef]

75. Azam, F.; Hemmingsen, B.B.; Volcani, B.E. Germanium incorporation into the silica of diatom cell walls. Arch. Mikrobiol. 1973, 92, 11-20. [CrossRef]

76. Richter, O. Zur Physiologie der Diatomeen, I., III. Sitzungsberichte der Kais. Akad. der Wissenschaften, Math. Klasse 1906, 115, 27-119.

77. Nichols, H.W. Growth media-freshwater. In Handbook of Phycological Methods: Culture Methods and Growth Measurements; Stein, J.R., Ed.; Cambridge University Press: Cambridge, UK, 1973; pp. 7-24. ISBN 9780521297479.

78. Delalat, B.; Sheppard, V.C.; Rasi Ghaemi, S.; Rao, S.; Prestidge, C.A.; McPhee, G.; Rogers, M.L.; Donoghue, J.F.; Pillay, V.; Johns, T.G.; et al. Targeted drug delivery using genetically engineered diatom biosilica. Nat. Commun. 2015, 6, 1-11. [CrossRef] [PubMed]

(C) 2020 by the authors. Licensee MDPI, Basel, Switzerland. This article is an open access article distributed under the terms and conditions of the Creative Commons Attribution (CC BY) license (http://creativecommons.org/licenses/by/4.0/). 